\title{
抗癌薬体内動態情報に基づく個別投与設計法の基盤構築に関する研究
}

\author{
濱田哲暢
}

\section{Development of an Individualized Therapy for Establishing the Optimal Dosage by the Pharmacokinetics Profiles of Anticancer Agents}

\author{
Akinobu HAMADA \\ Department of Pharmacy, Kumamoto University Hospital, 1-1-1 Honjo \\ Kumamoto 860-8556, Japan
}

(Received April 4, 2005)

\begin{abstract}
Therapeutic drug monitoring (TDM) is widely applied to a variety of medications, including antibiotics, immunosuppressants, and antidepressants, but the clinical utility of TDM for anticancer agents is currently limited by several factors. The primary reason is the poorly-defined concentration-effect relationships for most anticancer drugs. TDM has the potential to improve the clinical use of anticancer agents. This paper reviews the relations between the pharmacokinetics of a new anticancer agent, amrubicin, and the clinical response and toxic side effects in patients. The plasma concentration of amrubicin peaked immediately after a bolus intravenous injection of the drug and declined in a biexponential manner thereafter, whereas that of C-13 hydroxy metabolite amrubicinol also peaked just after amrubicin injection but decreased more gradually compared with that of amrubicin. The apparent total clearance of amrubicin showed a large interindividual variability, despite adjustment of dosage for body surface area. Leukocytopenia of grades 3 or 4 occurred in most patients, and thrombocytopenia and anemia of grades 3 or 4 were also common. Since the area-under the curves of amrubicin and amrubicinol seemed to be associated with the severity of hematological toxicities, it is thought that the plasma concentration of amrubicin and amrubicinol may provide useful information for establishing the optimal dosage of amrubicin in each patient.
\end{abstract}

Key words_amrubicin; amrubicinol; therapeutic drug monitoring

\section{1. はじめに}

抗癌薬の投与ではしばしば重篤な有害作用が発生 し，致死的であることが知られている．抗癌薬と他 の薬物が用量設定において異なる点は，患者が治療 に耐えられる最大投与量が至適投与量として設定さ れていることである.このため, 薬物動態の個人差 により強い副作用を引き起こされることから，患者 個々に合わせた投与設計が必要である。治療効果の 改善と有害作用の回避を目的とした個別化投与設計 として, therapeutic drug monitoring (TDM) が抗 菌薬, 抗てんかん薬, 免疫抑制薬などを対象に実施 されている。しかしながら，治療域が狭い抗癌薬へ の TDM の適用は研究途上と考えられる. ${ }^{1)}$ 抗癌薬

熊本大学医学部附属病院薬剤部 (医学薬学研究部臨床 薬物動態学分野）（下860-8556 熊本市本荘 1-1-1) e-mail: ahamada@kaiju.medic.kumamoto-u.ac.jp 本総説は, 平成 16 年度日本薬学会九州支部学術奨励賞 の受賞を記念して記述したものである.
の TDM を実地医療に導入する際の問題点として,

1）薬物動態パラメータと抗腫瘍効果及び有害作用 との相関が明確でないこと，2）薬理効果及び副作 用の発現にラグタイムが存在するため, 薬物血中濃 度と薬理作用の因果関係を定量化することが困難で あること，3）複数の抗癌薬と併用されることから 解析が複雑であること, ${ }^{2)}$ 4）患者個々における薬剤 感受性だけでなく, 前治療の有無が薬理効果と副作 用に影響することなどが挙げられる。しかしなが ら, 抗癌薬の血中濃度と抗腫瘍効果及び副作用との 関連を評価することは，個別投与設計法の開発にお いて必要と考えられる。本研究では, 新規肺癌治療 薬 amrubicinに着眼し, 既治療肺癌患者を対象に amrubicin 及び活性代謝物である amrubicinol の薬 物体内動態試験を実施し，血中濃度と用量制限因子 である血液毒性並びに抗腫瘍効果との関連性につい て検討した. 


\section{Amrubicin について}

Amrubicin は化学的に全合成された新規アントラ サイクリン系抗癌薬であり, ${ }^{3-5)}$ 小細胞肺癌及び非 小細胞肺癌に対し適応承認を取得しており，添付文 書における用法用量は $45 \mathrm{mg} / \mathrm{m}^{2} /$ day 3 日間連日 投与である。Amrubicin の代謝は doxorubicin と異 なり, doxorubicin では 13 位のケトンがカルボニル 還元酵素により水酸化され不活化されるが，amrubicin では抗腫瘍活性が 10 から 100 倍高い amrubicinol へ変換される（Fig. 1).

\section{3. 化学療法既治療肺癌患者における Amrubicin} の毒性

小細胞肺癌又は非小細胞肺癌と診断された 6 例の 患者に，添付文書に従い amrubicin（カルセド®， 住友製薬株式会社） $45 \mathrm{mg} / \mathrm{m}^{2} /$ day 3 日間静脈内 投与を行った。副作用評価は NCI-CTC（ver.2）に 準じて行った。患者背景を Table 1，血液毒性を Table 2 に示す。 6 例とも化学療法既治療患者であ り, Grade 3 以上の白血球減少 5 例, 好中球減少 6 例，血小板減少 3 例，へモグロビン減少 3 例が認め られた。Patient 1 及び 5 は輸血を必要とする重篤 なものであった．化学療法既治療患者に対する血液 毒性が高頻度に認められたことにより，化学療法未 治療患者を対象に設定された現在の投与量は, ${ }^{6,7)}$ 化 学療法既治療患者に対しては過量投与の可能性があ ると医師と協議の上で判断した，既治療肺癌患者に 対する amrubicinの投与量は減量される必要がある と考えられるが，添付文書には患者毎の特性に応じ て「投与量を適宜増減」と記載されているのみであ る。そこでわれわれは, amrubicinの個別投与設計
並びに安全性確保を目的として，既治療肺癌患者を 対象にした体内動態解析を実施した.

\section{Amrubicin 及び Amrubicinol の血漿中薬物濃}

\section{度の推移}

Amrubicin の個別投与設計に体内動態の把握が必 要であるため, amrubicin 及び活性代謝物 amrubicinol の血中濃度と抗腫瘍効果，副作用との相 関性を評価した。Amrubicin と amrubicinol の血中 濃度は HPLC 法にて測定した。なお，本試験は熊 本大学医学部附属病院医療・治験 - 倫理審議委員会 （IRB）の承認を得て実施した。Amrubicin 30 及 び $35 \mathrm{mg} / \mathrm{m}^{2}$ 投与した 2 例の患者の血中濃度時間推 移を Fig. 2 に示す. Amrubicinの血漿中濃度は投与 直後から速やかに減少しその後緩やかに消失した. Amrubicinol 濃度はいずれも投与直後に最高になり 緩やかに減少しており，それぞれの消失半減期は， $30 \mathrm{mg} / \mathrm{m}^{2}$ 投与で 4.3 分と 13.6 分, $35 \mathrm{mg} / \mathrm{m}^{2}$ 投与 で 6.2 分と 17.5 分であった.

血中濃度モニタリングを実施した 16 例の薬物動 態パラメータを Table 3 に示す. Amrubicin に対す る amrubicinol の投与後 24 時間の AUC 比は 30 か ら $45 \mathrm{mg} / \mathrm{m}^{2}$ の投与量範囲において $15.1 \pm 4.6 \%$ で あった。 Doxorubicin と doxorubicinol の AUC 比 は 40-90\%と報告されていることから, ${ }^{8)}$ amrubicin から amrubicinolへの変換率は比較的小さいと 考えられる。，一方，Fig. 3 に示すように amrubicin と amrubicinol の total AUC の間には有意な相関が 認められた（r=0.903, $p<0.0001 ） （$ Fig. 3$)$ 。この 高い相関は, amrubicin から amrubicinol への変換 の個人間変動が小さいことを示唆している。しかし

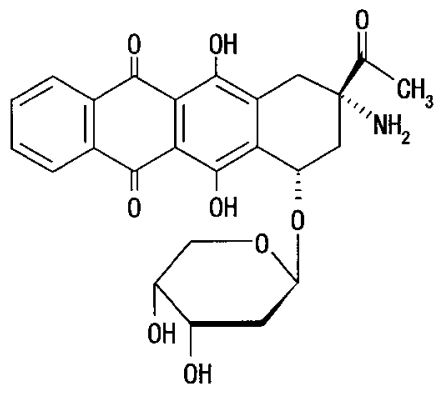

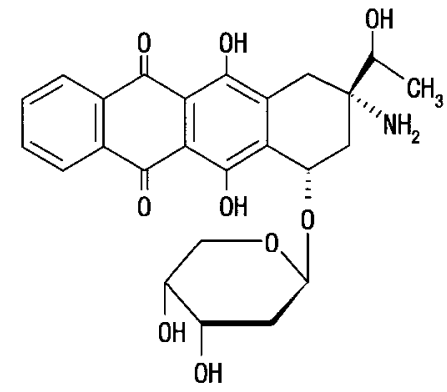

\section{Amrubicin}

\section{Amrubicinol}

Fig. 1. Chemical Structures of Amrubicin and Amrubicinol 
Table 1. Patient Characteristics

\begin{tabular}{cccccccc}
\hline $\begin{array}{c}\text { Patient } \\
\text { no. }\end{array}$ & $\begin{array}{c}\text { Age } \\
\text { (years) }\end{array}$ & Sex & $\begin{array}{c}\text { BSA } \\
\left(\mathrm{m}^{2}\right)\end{array}$ & $\begin{array}{c}\text { ECOG } \\
\text { performance status }\end{array}$ & Histology & $\begin{array}{c}\text { Disease } \\
\text { stage at } \\
\text { study entry }\end{array}$ & Previous therapy \\
\hline 1 & 67 & M & 1.39 & 2 & NSCLC & IV & Vinorelbine \\
Gefitinib & Surgery \\
2 & 63 & M & 1.50 & 1 & SCLC & IIIb & Cisplatin + irinotecan \\
Carboplatin+ etoposide \\
Carboplatin + irinotecan \\
4
\end{tabular}

ECOG: Eastern Cooperative Oncology Group, BSA: Body Surface Area, M: Man, NSCLC: Non-Small-Cell Lung Cancer, SCLC: Small-Cell Lung Cancer. ECOG performance status, these scales and criteria are used to assess how a patient's disease is progressing, assess how the disease affects the daily living abilities of the patient, and determine appropriate treatment and prognosis. 0: Fully active, able to carry on all pre-disease performance without restriction. 1: Restricted in physically strenuous activity but ambulatory and able to carry out work of a light or sedentary nature, e.g., light house work, office work. 2: Ambulatory and capable of all selfcare but unable to carry out any work activities. Up and about more than $50 \%$ of waking hours. 3: Capable of only limited selfcare, confined to bed or chair more than $50 \%$ of waking hours. 4: Completely disabled. Cannot carry on any selfcare. Totally confined to bed or chair. 5: Dead. Disease Stage: Classify the extent of disease. Stage 0: Cancer in situ (limited to surface cells). Stage I: Cancer limited to the tissue of origin, evidence of tumor growth. Stage II: Limited local spread of cancerous cells. Stage III: Extensive local and regional spread. Stage IV: Distant metastasis.

Table 2. Hematologic Toxicities in Previously Chemotherapy-treated Patients Treated with Amrubicin at a Dosage of $45 \mathrm{mg} / \mathrm{m}^{2}$ per Day for Three Consecutive Days

\begin{tabular}{cclcc}
\hline \hline & Leucocytopenia & Neutrocytopenia & Thrombocytopenia & Anemia \\
\hline Patient 1 & Grade 4 & Grade 4 (6 days) & Grade 4 & Grade 3 \\
Patient 2 & Grade 2 & Grade 3 & Grade 1 & Grade 1 \\
Patient 3 & Grade 4 & Grade 4 (8 days) & Grade 4 & Grade 3 \\
Patient 4 & Grade 3 & Grade 4 (2 days) & Grade 1 & Grade 2 \\
Patient 5 & Grade 4 & Grade 4 (10 days) & Grade 4 & Grade 3 \\
Patient 6 & Grade 3 & Grade 3 & Grade 1 & - \\
\hline$\%$ of $\geq 3$ toxicity & $83 \%$ & $100 \%$ & $50 \%$ & $50 \%$ \\
\hline
\end{tabular}

Dash $(-)$ means that no hematologic toxicity was observed. The duration lasting the toxicity was in parenthesis. Grades refer to the severity of the adverse event. NCI-CTC version 2.0 displays Grade 1 through 5 with unique clinical descriptions of severity for each adverse event based on this general guideline: Grade 1: Mild adverse event, Grade 2: Moderate adverse event, Grade 3: Severe adverse event, Grade 4: Life-threatening or disabling adverse event, Grade 5: Death related to adverse event.

ながら, amrubicinの主代謝酵素とされているカル ボニル還元酵素の活性に個体間変動が報告されてい ることから, amrubicin から amrubicinol への変換 にカルボニル還元酵素のみならずアルデヒド還元酵 素やジヒドロジオール脱水素酵素など，他の還元酵

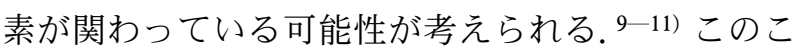
とから,さらに症例を集積して個人差に関して評価 することが必要と考えられる.
抗癌薬の投与量は体表面積（BSA）から計算さ れるが, ${ }^{12)}$ amrubicin の clearance (CL) は BSA に よる投与量補正にも関わらず大きな個体間変動が認 められており $(\mathrm{CV}=49.8 \%)$, amrubicin の CL と BSA の間には有意な相関は認められなかった（r= 0.402, $p=0.137$ ) (Fig. 4). Baker らは13)抗癌剤 33 種を調査し，そのうち 28 種はBSA による投与量 補正が CL における個体間変動を減少させるのに寄 


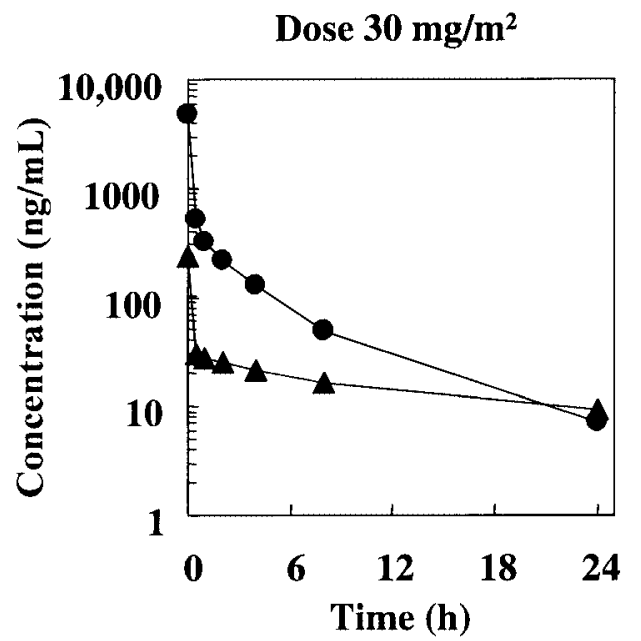

Fig. 2. Plasma Concentration-time Curves of Amrubicin Blood samples were collected at $0.5,1,2,4,8$, and $24 \mathrm{hr}$.

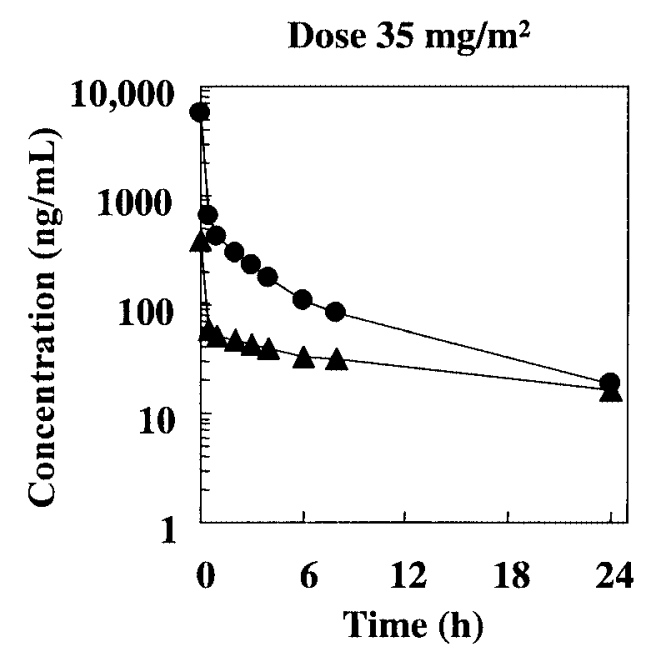

and Amrubicinol $(\mathbf{\Delta})$ in Patients Treated with Amrubicin

Table 3. Pharmacokinetic Parameters of Amrubicin and Amrubicinol after the First Administration of Amrubicin at a Dosage Ranging from 30 to $45 \mathrm{mg} / \mathrm{m}^{2}$ per Day

\begin{tabular}{|c|c|c|c|c|c|c|c|}
\hline \multirow{2}{*}{$\begin{array}{c}\text { Amrubicin } \\
\text { dosage } \\
\left(\mathrm{mg} / \mathrm{m}^{2}\right)\end{array}$} & \multirow{2}{*}{$\begin{array}{l}\text { No. of } \\
\text { patients }\end{array}$} & \multicolumn{3}{|c|}{ Amrubicin } & \multicolumn{2}{|c|}{ Amrubicinol } & \multirow{2}{*}{$\begin{array}{c}\text { AUC ratio } \\
(\%)\end{array}$} \\
\hline & & $\begin{array}{l}\text { Total AUC } \\
(\mathrm{ng} \cdot \mathrm{h} / \mathrm{ml})\end{array}$ & $\underset{(\mathrm{mg} / \mathrm{ml})}{\mathrm{C}_{\max }}$ & $\begin{array}{c}\mathrm{CL}_{\mathrm{app}} \\
(\mathrm{l} / \mathrm{h})\end{array}$ & $\begin{array}{l}\text { Total AUC } \\
(\mathrm{ng} \cdot \mathrm{h} / \mathrm{ml})\end{array}$ & $\underset{(\mathrm{ng} / \mathrm{ml})}{\mathrm{C}_{\max }}$ & \\
\hline 45 & 6 & & & & & & \\
\hline $\begin{array}{l}\text { Mean } \pm \mathrm{SD} \\
(\mathrm{CV}, \%)\end{array}$ & & $\begin{array}{c}13490 \pm 6854 \\
(50.8)\end{array}$ & $\begin{array}{c}3407 \pm 2613 \\
(76.7)\end{array}$ & $\begin{array}{c}15.4 \pm 8.3 \\
(53.9)\end{array}$ & $\begin{array}{c}2585 \pm 1671 \\
(64.7)\end{array}$ & $\begin{array}{c}94 \pm 56 \\
(59.8)\end{array}$ & $\begin{array}{c}17.9 \pm 4.7 \\
(26.3)\end{array}$ \\
\hline Range & & 5319-23802 & $979-6927$ & $6.3-28.9$ & $644-4640$ & $32-163$ & $11.9-22.5$ \\
\hline 40 & 3 & & & & & & \\
\hline $\begin{array}{l}\text { Mean } \pm S D \\
(\mathrm{CV}, \%)\end{array}$ & & $16706^{*}$ & $\begin{array}{c}4869 \pm 2444 \\
(46.1)\end{array}$ & $\begin{array}{c}8.8 \pm 2.6 \\
(29.1)\end{array}$ & $4097^{*}$ & $\begin{array}{c}333 \pm 139 \\
(41.7)\end{array}$ & $\begin{array}{c}17.5 \pm 3.9 \\
(22.6)\end{array}$ \\
\hline Range & & $14276-19135$ & $2584-7069$ & $6.5-11.6$ & $3976-4219$ & $200-477$ & $14.3-21.9$ \\
\hline 35 & 3 & & & & & & \\
\hline $\begin{array}{l}\text { Mean } \pm \text { SD } \\
(\mathrm{CV}, \%)\end{array}$ & & $\begin{array}{c}13447 \pm 4195 \\
(31.2)\end{array}$ & $\begin{array}{c}3349 \pm 2051 \\
(61.2)\end{array}$ & $\begin{array}{c}10.6 \pm 2.7 \\
(25.8)\end{array}$ & $\begin{array}{c}2325 \pm 468 \\
(31.2)\end{array}$ & $\begin{array}{c}162 \pm 131 \\
(80.9)\end{array}$ & $\begin{array}{c}12.2 \pm 1.5 \\
(11.9)\end{array}$ \\
\hline Range & & $9707-17983$ & $1104-5126$ & $7.5-12.8$ & $1869-2805$ & $51-306$ & $11.3-13.9$ \\
\hline 30 & 4 & & & & & & \\
\hline $\begin{array}{l}\text { Mean } \pm \text { SD } \\
(\mathrm{CV}, \%)\end{array}$ & & $\begin{array}{c}10262 \pm 2104 \\
(20.5)\end{array}$ & $\begin{array}{l}1867 \pm 1200 \\
(50.1)\end{array}$ & $\begin{array}{c}12.7 \pm 6.1 \\
(48.0)\end{array}$ & $\begin{array}{c}1514 \pm 263 \\
(46.0)\end{array}$ & $\begin{array}{c}87 \pm 40 \\
(46.0)\end{array}$ & $\begin{array}{c}11.2 \pm 3.0 \\
(26.8)\end{array}$ \\
\hline Range & & $8058-12838$ & $621-3330$ & $7.3-20.7$ & $1269-1858$ & $56-146$ & $14.1-16.6$ \\
\hline Grand & 16 & & & & & & \\
\hline $\begin{array}{l}\text { Mean } \pm \text { SD } \\
(\mathrm{CV}, \%)\end{array}$ & & & & $\begin{array}{c}12.6 \pm 6.3 \\
(49.8)\end{array}$ & & & $\begin{array}{c}15.1 \pm 4.6 \\
(30.8)\end{array}$ \\
\hline Range & & & & $6.3-28.9$ & & & $11.3-22.5$ \\
\hline
\end{tabular}

The AUC ratio refers to the ratio of the $\mathrm{AUC}_{0-24}$ of amrubicinol to that of amrubicin. ${ }^{*}$ Treatment stopped after the second daily dose in one patient due to toxicity. The value represents mean value.

与しないことを報告している. Amrubicinにおいて も BSA 以外の因子が体内動態を規定しているもの と考えられるが詳細は不明であり，今後さらなる検 討が必要と思われる.

\section{5. 毒性発現・抗腫瘍効果に対する薬物動態の影} 響

毒性の評価は第 1 サイクルにて行った。主な副作 用は血液毒性であり，非血液毒性は相対的に軽度で あった. Figure 5 に薬物動態パラメータ (AUC) と 血液毒性の関連を示す。Amrubicin と amrubicinol 


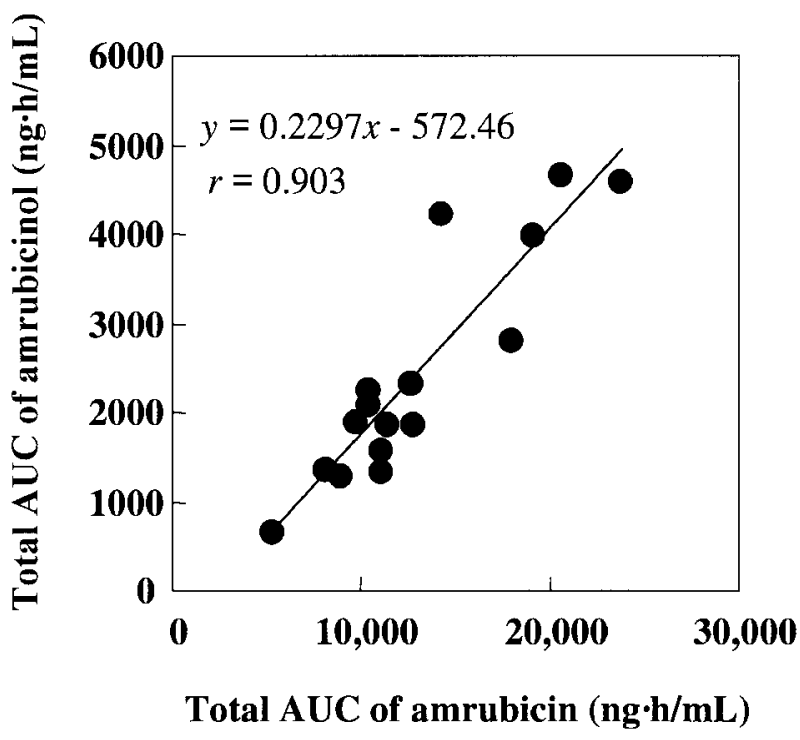

Fig. 3. Relationship between Area under the Curves (AUCs) of Amrubicin and Amrubicinol in Patients Treated with Amrubicin for 3 Consecutive Days (Spearman's Correlation Coefficient $=0.826 ; \mathrm{r}=0.903, p<0.0001$, Univariable Linear Regression Analysis)

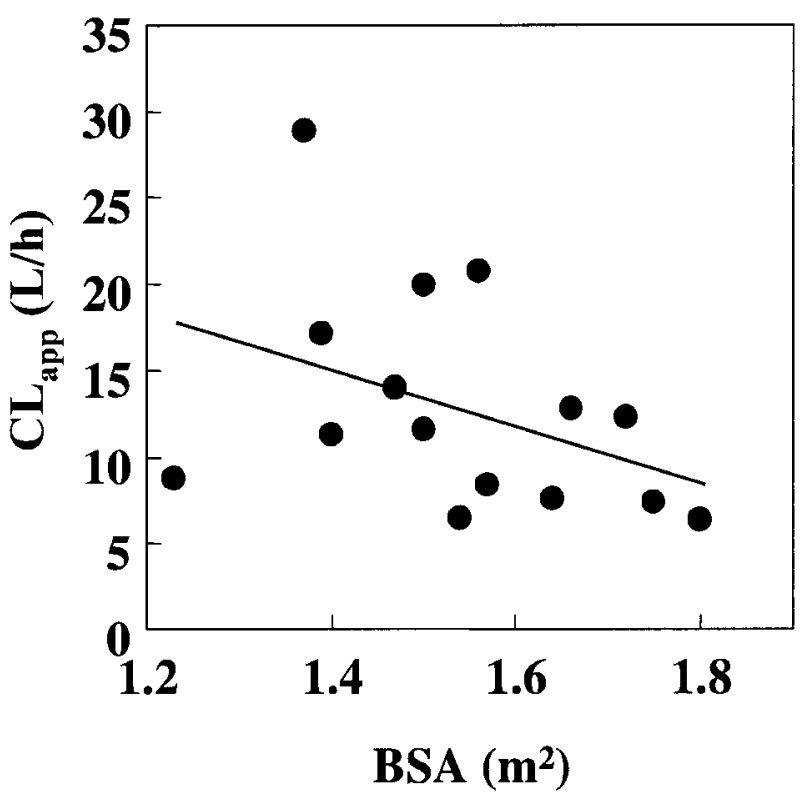

Fig. 4. Relationship between Body Surface Area (BSA) and Apparent Total Clearance $\left(\mathrm{CL}_{\mathrm{app}}\right)$ of Amrubicin in Patients Treated with Amrubicin at the Dose of 30 to $45 \mathrm{mg} / \mathrm{m}^{2}$ (Spearman's Correlation Coefficient $=-0.493, \mathrm{r}=0.402, p$ $=0.137$, Univariable Linear Regression Analysis)

のAUC は強い血液毒性を認めた患者群で高い傾向 が認められた。特に, 活性代謝物である amrubicinol の AUC と白血球減少との間には有意な相関が認め られた $(p=0.011)$. 理由として, amrubicinより amrubicinol の細胞傷害活性が強く生物学的半減期 の長いためと考えられる。一方，抗腫瘍効果と AUC に相関は認められなかった（Fig. 6)。抗腫瘍 効果に個体差が生じる原因は，抗癌薬に対する患者 個々の感受性だけでなく，前治療及び腫瘍の組織型 の違いなど複雑な要因が混在するため解析が困難で ある場合が多い。しかしながら，安全性を確保した 化学療法の実施は臨床上極めて重要であり，抗癌薬 の投与量が医師の匙加減でなく, 患者個々の薬物動 態に従って調整されることは，科学的根拠に基づい た合理的な投与設計に繋がるものと期待される.

\section{6. まとめ}

本研究では, 癌化学療法既治療患者における amrubicinの体内動態特性並びに本剂の用量制限因子 である血液毒性並びに抗腫瘍効果と薬物血中濃度の 関連を検討した。 Amrubicinの投与量は添付文書に おいて $45 \mathrm{mg} / \mathrm{m}^{2}$ の 3 日間連日投与が用法・用量と して記載されているが，すべての患者に grade 3 以 上の強い血液毒性が発現したことから，化学療法既 治療患者における amrubicin の投与量の設定に注意 が必要と思われた。添付文書には薬物治療を実施す る上で有用な医薬品情報が記載されているが，臨床 試験 (治験)では少数の患者を対象に行われるため, 実地医療で初めて予期せ女副作用が発生するなど安 全性情報が不十分である場合がある。そのため，添 付文書の記載事項を客観的に評価することが必要と 考えられる。

抗癌薬は副作用が重篤かつ治療域が狭い薬物であ り，過量投与による副作用は重篤であり死に至る場 合もある.Amrubicin の血液毒性はしばしば重篤化 することから，副作用を回避した投与設計が望まし いと思われる．現在，われわれはさらに例数を集積 し，amrubicin 及び amrubicinol の目標血中濃度の 設定と効果及び副作用との相関を解析している．抗 癌薬の作用は患者個々の感受性及び薬物動態など多 くの因子により規定されるが，個別化投与設計法の 確立に患者個々の抗癌薬の体内動態情報が有用な指 標となることを期待したい.

謝辞本研究は熊本大学医学部附属病院薬剂部 (医学薬学研究部臨床薬物動態学分野) 及び同呼吸 器病態学分野にて行われた共同研究であり, ご指導 ご鞭撻を賜りました薬剤部 齋藤秀之教授並びに呼 


\section{Leukocytopenia}

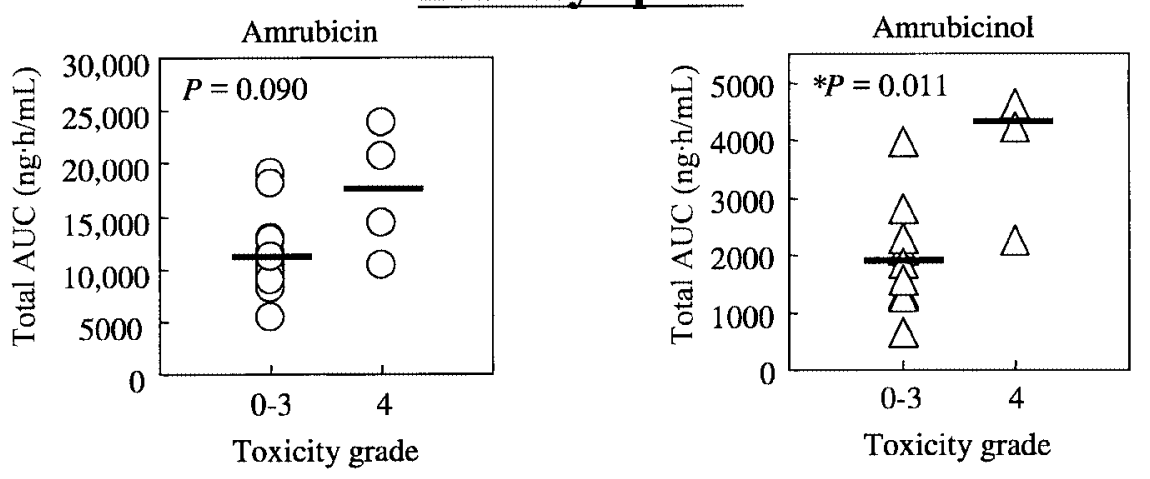

Thrombocytopenia
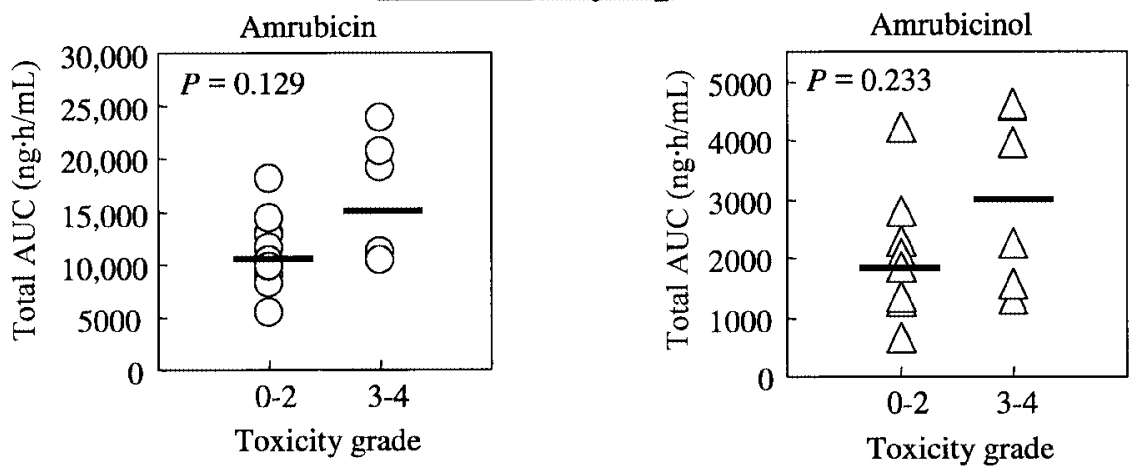

\section{$\underline{\text { Anemia }}$}
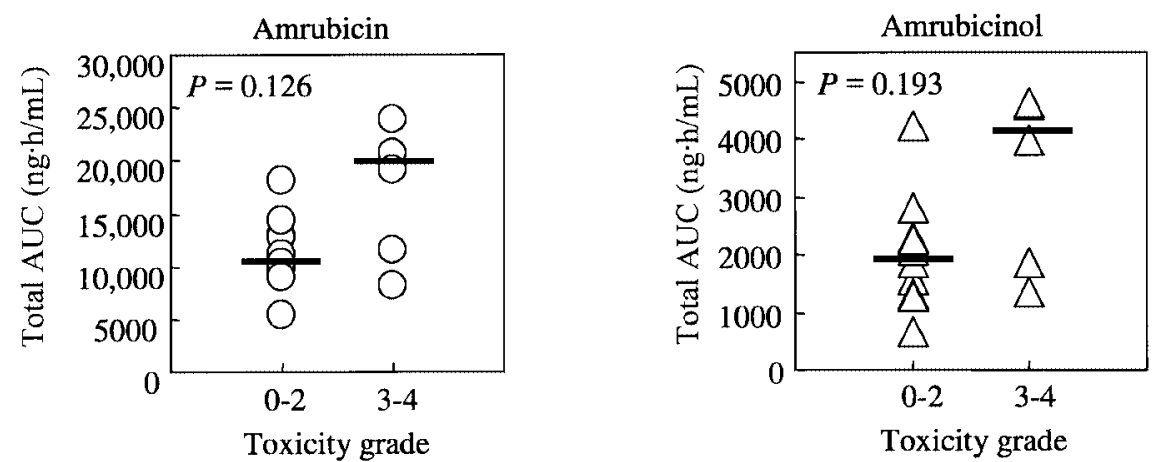

Fig. 5. Distributions of Total AUCs of Amrubicin (O) and Amrubicinol $(\triangle)$ as a Function of Hematologic Toxicity Grades in Patients Treated with the First Cycle of Amrubicin

Patients were grouped according to whether they experienced low or high hematologic toxicities, as indicated. Horizontal bars represent the median total AUC values for each group.
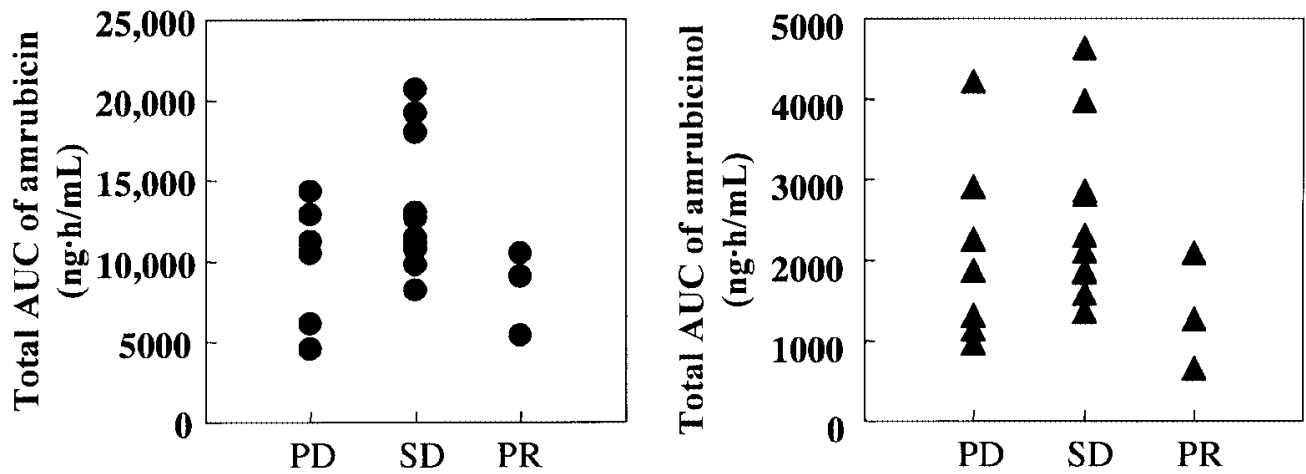

Fig. 6. Relationship between AUC and Clinical Response

Points represent the observed AUC of amrubicin $(O)$ and amrubicinol $(\triangle)$ values for individual patient. PD: progressive disease, SD: stable disease, PR: partial response. 
吸器病態学分野 岡本 勇博士 (現近畿大学医学部 腫瘍内科）に深甚なる謝意を表します。また，研究 遂行に多大なご協力を頂いた松永雄亮修士並びに臨 床薬物動態学分野教室の皆様に深く感謝申し上げま す.

\section{REFERENCES}

1) Hon Y. Y., Evans W. E., Clin. Chem., 44, 388 -400 (1998).

2) Loadman P. M., Bibby M. C., Clin. Pharmacokinet., 26, 486-500 (1994).

3) Hanada M., Noguchi T., Murayama T., Nippon Yakurigaku Zasshi, 122, 141-150 (2003).

4) Yamaoka T., Hanada M., Ichii S., Morisada S., Noguchi T., Yanagi Y., Jpn. J. Cancer Res., 89, 1067-1073 (1998).

5) Noguchi T., Ichii S., Morisada S., Yamaoka T., Yanagi Y., Jpn. J. Cancer Res., 89, 10551060 (1998).

6) Yana T., Negoro S., Takada Y., Yokota S.,
Fukuoka M., Proc. Am. Soc. Clin. Oncol., 17, 450a (1998).

7) Furuse K., Ikegami H., Ariyoshi Y., Ann. Oncol., 88, 422 (1998).

8) Speth P. A., van Hoesel Q. G., Haanen C., Clin. Pharmacokinet., 15, 15-31 (1988).

9) Wong J. M., Kalow W., Kadar D., Takamatsu Y., Inaba T., Pharmacogenetics, 3, 110-115 (1993).

10) Ohara H., Miyabe Y., Deyashiki Y., Matsuura K., Hara A., Biochem. Pharmacol., 50, 221227 (1995).

11) Lopez de Cerain A., Marin A., Idoate M. A., Tunon M. T., Bello J., Eur. J. Cancer, 35, 320 -324 (1999).

12) Sawyer M., Ratain M. J., Invest. New Drugs, 19, 171-177 (2001).

13) Baker S. D., Verweij J., Rowinsky E. K. Donehower R. C., Schellens J. H., Grochow L. B., Sparreboom A., J. Natl. Cancer Inst., 94, 1883-1888 (2002). 